International Business and Global Economy 2018, no. 37, pp. 142-156

Biznes międzynarodowy w gospodarce globalnej 2018, nr 37, s. 142-156

Edited by the Institute of International Business, University of Gdańsk

ISSN 2300-6102

e-ISSN 2353-9496

DOI 10.4467/23539496IB.18.010.9383

Anna Odrobina

Uniwersytet Ekonomiczny w Krakowie

Paweł Folfas

Szkoła Główna Handlowa w Warszawie

\title{
Intensywność nakładów na badania i rozwój w regionach Unii Europejskiej w ujęciu przestrzennym
}

Celem opracowania jest sprawdzenie, czy występuje przestrzenna autokorelacja między regionami NUTS 2 w UE $w$ intensywności nakładów na $B+R$. Wykorzystano trzy metody badawcze: studia literaturowe, analizę danych dotyczących udziału nakładów na $\mathrm{B}+\mathrm{R} w \mathrm{w}$ PKB regionów oraz statystykę Morana I, która jest podstawową miarą zależności między obserwacjami w przestrzeni geograficznej. Przeprowadzone badanie wykazało brak globalnej i lokalnej autokorelacji przestrzennej opartej na odwrotności geograficznej odległości między NUTS 2. Stwierdzono natomiast istnienie słabej dodatniej autokorelacji przestrzennej opartej na posiadaniu wspólnej granicy, tak w ujęciu globalnym, jak i lokalnym. W przestrzeni europejskiej zidentyfikowane zostały dwa klastry (obejmujące trzy regiony w Belgii oraz pięć regionów w Niemczech). Wobec znaczących dysproporcji przestrzennych między regionami w UE występowanie klastrów stanowi zjawisko rzadkie. Dla powstania klastra regionów o wysokiej intensywności $B+R$ niezbędne jest sąsiedztwo regionów posiadających ośrodki metropolitalne, z rozbudowaną infrastrukturą akademicko-badawczą oraz rozwiniętą sferą biznesu, silnie zaangażowaną $\mathrm{w} B+\mathrm{R}$, a ponadto specjalizacja regionalna $\mathrm{w}$ podobnych branżach o wysokiej wiedzochłonności.

Słowa kluczowe: badania i rozwój, zróżnicowanie regionalne, autokorelacja przestrzenna, UE, NUTS 2

Klasyfikacja JEL: C21, O30, R12

\section{R\&D intensity in the European Union's regions - spatial approach}

The aim of the study is to verify the existence of spatial autocorrelation among the EU NUTS 2 regions in the case of R\&D intensity. Three research methods were used, namely literature studies, analysis of data on the share of expenditure on R\&D in regional GDP, and Moran I statistics which is the basic measure of spatial dependencies between observations in the geographical space. The study showed that there exists neither global nor local spatial autocorrelation based on the inverse geographical distance among NUTS 2. However, it was found that there is a weak positive spatial autocorrelation based on having a common border both globally and locally. Two clusters have been identified in the European space (covering three regions in Belgium and five regions in Germany). In view of the significant spatial disparities between EU regions, the occurrence of clusters is a rare phenomenon. For the establishment of a cluster of regions with high R\&D intensity, it is necessary to have metropolitan centers with extensive academic and research infrastructure, 
developed business strongly involved in R\&D, and regional specialization in similar highly knowledge-intensive industries.

Keywords: research and development, regional inequalities, spatial autocorrelation, EU, NUTS 2

JEL classification: C21, O30, R12

\section{Wprowadzenie}

Powszechnie uznaje się, że jednym z kluczowych wskaźników oceny potencjału badawczego i technologicznego kraju lub regionu, zwłaszcza w kontekście międzynarodowych czy międzyregionalnych porównań, jest intensywność nakładów na $\mathrm{B}+\mathrm{R}$, mierzona jako udział całkowitych nakładów na $\mathrm{B}+\mathrm{R}$ (Gross Expenditure on Research \& Development - GERD) w PKB.

Cel badania stanowiło sprawdzenie, czy istnieje przestrzenna autokorelacja między regionami NUTS 2 UE-28 pod względem intensywności nakładów na B + R. Aby zmierzyć zależności przestrzenne, zastosowano statystykę Morana I, która służy do pomiaru globalnej i lokalnej autokorelacji przestrzennej. W analizie wykorzystano dwa rodzaje macierzy wag przestrzennych definiujących sąsiedztwo jako posiadanie wspólnej granicy lądowej oraz jako odwrotność odległości między geometrycznymi środkami regionów.

Opracowanie składa się z czterech zasadniczych części. W pierwszej przedstawiono przegląd badań odnośnie do regionów UE w kontekście działalności $B+R$, druga zawiera ogólną charakterystykę intensywności nakładów na $B+R$ w NUTS 2, w trzeciej opisano metodę badawczą, czwarta zaś obejmuje wyniki analizy autokorelacji przestrzennej między regionami NUTS $2 \mathrm{w}$ UE.

\section{Przegląd literatury}

Dysproporcje rozwojowe między regionami Unii Europejskiej są od wielu lat przedmiotem zainteresowania zarówno polityki, jak i badań naukowych. Wysiłki UE w kierunku konwergencji regionalnej podejmowane są od dawna w ramach polityki spójności, która podlega ocenie i przekształceniom [Bachtler, Wren, 2006, s. 143-153; McCann, Ortega-Argilés, 2015, s. 1291-1302].

Jednym z kluczowych wyzwań UE jest oparcie gospodarki na wiedzy i innowacjach, a działania ze szczebla UE realizowane są przez strategię Europa 2020. Między państwami członkowskimi UE wciąż jednak występują znaczne dysproporcje $\mathrm{w}$ potencjale B+R [Barber, Scherngell, 2013, s. 1283-1291; Frietsch, Rammer, Schubert, 2015, s. 9-15], chociaż wskazuje się na symptomy konwergencji w tej kwestii [Archibugi, Filippetti, 2011], a nawet na pewne płaszczyzny o wysokim 
stopniu koncentracji, np. jeśli chodzi o lokalizację biznesu [Veugelers, Cincera, 2015, s. 4-9]. Natomiast na szczeblu regionalnym widoczne są nie tylko znacznie większe, ale nasilające się dysproporcje [Bottazzi, Peri, 2002; Stephan, Happich, Geppert, 2005; Gossling, Rutten, 2007, s. 253-270; European Commission, 2009; Paas, Vahi, 2012; Aristovnik, 2014; European Union, 2017], które uważa się za poważne bariery wzrostu całego ugrupowania [Bilbao-Osorio, Rodríguez-Pose, 2004, s. 434-455; Sterlacchini, 2008, s. 1096-1107; Piras, Postiglione, Aroca, 2012, s. 35-51; Polasek, Sellner, 2013].

W tej sytuacji uwaga UE, tak ze strony polityki spójności, jak i polityki $B+R$, skupia się na wspierania potencjału technologicznego regionów. Coraz mocniej akcentuje się przy tym podejście przestrzenne [Martín, Mulas-Granados, Sanz, 2005, s. 41-61; Maggioni, Uberti, 2007, s. 230-255; Narula, Santangelo, 2009, s. 393-403], które uwzględnia specyfikę każdego regionu, wymagającą stosowania indywidualnie dopasowanych narzędzi wsparcia [Benos, Karagiannis, Karkalakos, 2015; McCann, Ortega-Argilés, 2015, s. 1291-1302; Rodríguez-Pose, 2015]. Zgodnie z aktualnym podejściem potencjał badawczy i technologiczny regionu zależy od szeregu specyficznych czynników, takich jak kultura biznesu, kapitał ludzki, edukacja i instytucje badawcze, usługi wspierające innowacje, mechanizmy transferu technologii, infrastruktura regionalna, mobilność badaczy, źródła finansowania czy pomysłowość podmiotów w regionie [Peiro-Palomino, 2016; European Union, 2017, s. 152], ale także od czynników geograficznych, co prowadzi do przestrzennej koncentracji potencjału innowacyjnego oraz wzrostu dysproporcji międzyregionalnych w UE [Alexiadis, Korres, 2010; de Dominicis, Florax, de Groot, 2011; Furková, Chocholatá, 2017].

Podsumowując, z przeglądu literatury wynika, że nie należy się spodziewać silnej dodatniej autokorelacji przestrzennej między regionami NUTS 2 pod względem intensywności nakładów na $B+R$. Bardzo prawdopodobny jest brak klastrów - w szczególności grupujących regiony o wysokiej intensywności nakładów na $\mathrm{B}+\mathrm{R}$ - lub bardzo mała ich liczba.

\section{Intensywność nakładów na B+R w NUTS 2}

Analizując regiony NUTS 2 z najwyższą i najniższą intensywnością nakładów na $B+R$, widać bardzo znaczące zróżnicowanie. Jak pokazuje rysunek 1, w $2013 \mathrm{r}$. wskaźnik przyjmował wartości od 8,80\% (belgijski region Brabancja Walońska Brabant Wallon) do 0,06\% (Region Południowo-Wschodni-Sud-Est - w Rumunii). 


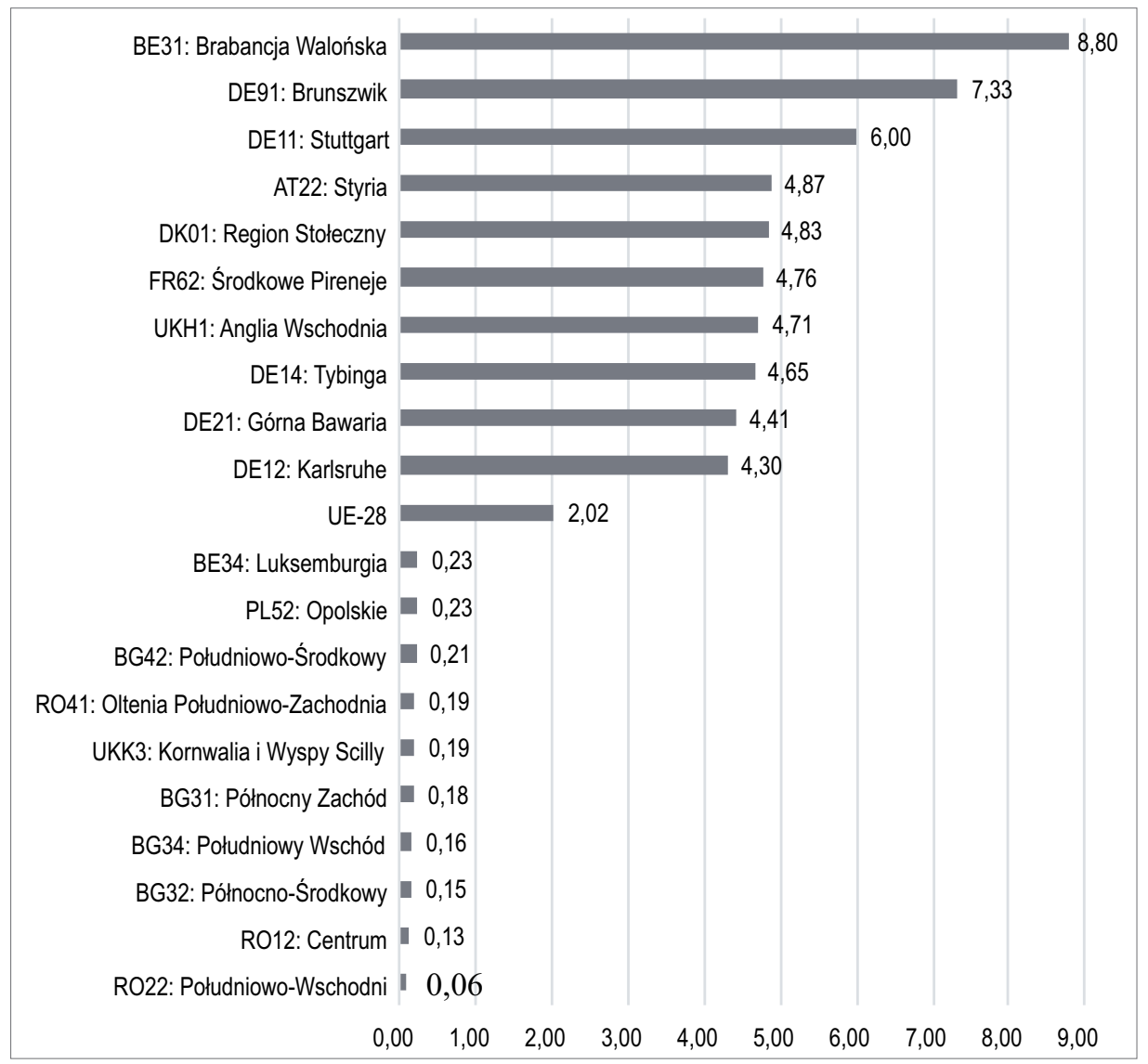

Rys. 1. Regiony UE z najwyższą i najniższą intensywnością nakładów na B+R w 2013 r. Źródło: Opracowanie własne na podstawie: [Eurostat, 2018].

Najwyższą intensywność nakładów na $\mathrm{B}+\mathrm{R}$ wykazują często regiony zurbanizowane, z dużym ośrodkiem miejskim (Hanower w Brunszwiku - Braunschweig, Stuttgart w regionie Stuttgart, Graz w Styrii - Steiermark, Kopenhaga w Regionie Stołecznym - Hovedstaden, Tuluza w Środkowych Pirenejach - Midi-Pyrénées, Monachium w Górnej Bawarii - Oberbayern, Karlsruhe w regionie Karlsruhe). Warto podkreślić, że tylko w przypadku duńskiego regionu mamy do czynienia z regionem stołecznym. W pozostałych przypadkach są to ważne ośrodki metropolitalne w gospodarce narodowej, których wysoki potencjał badawczo-rozwojowy wynika z umiejscowienia tu znaczących ośrodków uniwersyteckich i instytucji badawczych, lokalizacji $\mathrm{w}$ regionie przedsiębiorstw zaangażowanych $\mathrm{w}$ realizację nakładów na B+R i ze specjalizacji regionu w branżach wiedzochłonnych (tab. 1).

Chociaż nie wszystkie regiony z czołówki posiadają ośrodek metropolitalny, to dzięki lokalizacji uniwersytetów i instytucji badawczych oraz przedsiębiorstw 
$\mathrm{z}$ branż wiedzochłonnych cechują się wysoką koncentracją na działalności $\mathrm{B}+\mathrm{R}$. Lider rankingu, belgijski region Brabancja Walońska, zawdzięcza swoją pozycję dziewięciu uczelniom wyższym, $\mathrm{z}$ uniwersytetem $\mathrm{w}$ Louvain na czele, oraz licznym firmom zlokalizowanym $w$ regionie ( $w$ tym $w$ parku technologicznym) z branży farmaceutycznej (z GlaxoSmithKline Biologicals), IT oraz chemicznej. Nie bez znaczenia jest $\mathrm{w}$ tym przypadku bezpośrednie sąsiedztwo $\mathrm{z}$ regionem Brukseli. Z kolei region Anglia Wschodnia (East Anglia) najwyższą w Wielkiej Brytanii intensywność nakładów na $B+R$ osiąga dzięki sześciu uniwersytetom, z University of Cambridge oraz University of East Anglia na czele. Chociaż w tym regionie ośrodkami miejskimi są względnie nieduże Norwich, Cambridge, Peterborough i Ipswich, to jednak potencjał uniwersytetów oraz strefy przemysłowej plasuje ten region w czołówce UE. Natomiast niemiecki region Tybinga (Tübingen) znany jest z osiągnięć licznych instytucji badawczych ukierunkowanych na nauki biologiczne oraz systemy inteligentne, co pozwala mu osiągnąć wysoki udział nakładów na $\mathrm{B}+\mathrm{R}$ w $\mathrm{PKB}$.

Tabela 1. Znaczenie biznesu w B+R regionów o najwyższej intensywności nakładów na $B+R$

\begin{tabular}{|l|c|c|l|}
\hline \multicolumn{1}{|c|}{ Region } & $\begin{array}{c}\text { BERD } \\
\text { jako \% PKB }\end{array}$ & $\begin{array}{c}\text { Udział BERD } \\
\text { w GERD (w \%) }\end{array}$ & \multicolumn{1}{|c|}{ Najważniejsze branże w regionie } \\
\hline BE31: Brabancja Walońska & b.d. & b.d. & farmaceutyczna, IT, chemiczna \\
\hline DE91: Brunszwik & 5,37 & 73,26 & motoryzacyjna, elektrotechniczna, IT \\
\hline DE11: Stuttgart & 5,48 & 91,33 & $\begin{array}{l}\text { motoryzacyjna, ICT, kreatywna, } \\
\text { energetyczna }\end{array}$ \\
\hline AT22: Styria & 3,64 & 74,74 & $\begin{array}{l}\text { motoryzacyjna, elektroniczna, zielo- } \\
\text { nych technologii }\end{array}$ \\
\hline DK01: Region Stołeczny & 3,25 & 67,29 & $\begin{array}{l}\text { biotechnologiczna, zielonych tech- } \\
\text { nologii, kreatywna }\end{array}$ \\
\hline FR62: Środkowe Pireneje & 3,38 & 71,01 & aeronautyki, ICT, farmaceutyczna \\
\hline UKH1: Anglia Wschodnia & 2,97 & 63,06 & $\begin{array}{l}\text { farmaceutyczna, ICT, elektroniczna, } \\
\text { biochemiczna }\end{array}$ \\
\hline DE14: Tybinga & 3,71 & 79,78 & $\begin{array}{l}\text { nauk biologicznych, systemów inte- } \\
\text { ligentnych }\end{array}$ \\
\hline DE21: Górna Bawaria & 3,32 & 75,28 & $\begin{array}{l}\text { motoryzacyjna, robotyki, mechatro- } \\
\text { niczna, farmaceutyczna }\end{array}$ \\
\hline DE12: Karlsruhe & 2,64 & 61,40 & motoryzacyjna, IT, elektrotechniczna \\
\hline
\end{tabular}

Źródło: Opracowanie własne na podstawie: [Eurostat, 2018; European Commission, 2018; oficjalne strony internetowe regionów].

Warte podkreślenia jest znaczenie sfery biznesu dla wysokiej intensywności nakładów na $\mathrm{B}+\mathrm{R}$. W regionach $\mathrm{z}$ czołówki UE nakłady na $\mathrm{B}+\mathrm{R}$ przedsiębiorstw (Business Expenditure on RED - BERD) stanowią w większości przypadków ponad 
70\% całkowitych nakładów w regionie (poza Karlsruhe, Anglią Wschodnią i Regionem Stołecznym w Danii, gdzie udział BERD w GERD był niższy), a najwyższy udział na poziomie 91,33\% odnotowała sfera biznesu w niemieckim regionie Stuttgart (tab. 1). Lokalizacja przedsiębiorstw intensywnie zaangażowanych w nakłady na $\mathrm{B}+\mathrm{R}$ wydaje się odgrywać kluczową rolę dla potencjału $\mathrm{B}+\mathrm{R}$ regionu. Sfera biznesu w regionie wpływa wydatnie na specjalizację regionu. Regiony o najwyższej intensywności nakładów na $\mathrm{B}+\mathrm{R}$ charakteryzują się rozwiniętą siecią przedsiębiorstw z branż wiedzochłonnych, jak motoryzacyjna, farmaceutyczna, biotechnologiczna, IT, ICT czy elektrotechniczna.

$Z$ kolei regiony o najniższej intensywności nakładów na $B+R$ stanowią przede wszystkim obszary peryferyjne bez większych ośrodków miejskich i obejmują zasadniczo regiony bułgarskie i rumuńskie, za wyjątkiem jednego regionu brytyjskiego (Kornwalii i Wysp Scilly - Cornwall and Isles of Scilly), jednego polskiego (Opolskie) oraz jednego belgijskiego (Luksemburgii). Przypuszczać należy, że zgodnie z regionalnym podziałem pracy regiony te wykonują inne zadania poza aktywnością badawczo-rozwojową, a ich bardzo niskie wskaźniki intensywności nakładów na $B+R$ wynikają bezpośrednio ze skromnych nakładów na $B+R$ w wielkościach bezwzględnych. Warto zauważyć, że w większości są to regiony z nowych państw członkowskich UE.

Ogólnie trzeba stwierdzić, że nowe państwa członkowskie UE wykazują niską intensywność nakładów na B+R (tab. 2). Tylko Słowenia osiąga wskaźnik wyższy niż średnia dla UE-28, natomiast większość pozostałych krajów nie przeznacza na $\mathrm{B}+\mathrm{R}$ nawet $1 \%$ PKB, przy czym najgorsza sytuacja jest $\mathrm{w}$ Rumunii $(0,39 \%)$, na Łotwie $(0,61 \%)$ i Bułgarii $(0,63 \%)$. Poza Słowenią względnie wysoką (choć niższą od unijnej średniej) intensywnością nakładów na B+R cechują się Czechy (1,9\%), Estonia (1,72\%) i Węgry (1,39\%).

Analizując intensywność nakładów na B+R na poziomie NUTS 2 w nowych państwach członkowskich, zaobserwować można, że regiony wykazują nikłą aktywność w działalności badawczo-rozwojowej, a względnie wyższą intensywnością cechują się regiony stołeczne, które na tle kraju są najlepiej rozwiniętymi ośrodkami gospodarczymi oraz uniwersyteckimi, dlatego tylko one osiągają intensywność nakładów na B + R wyższą niż średnia krajowa w Bułgarii, Chorwacji, Polsce, Rumunii, Słowacji i na Węgrzech. Świadczy to o dużych dysproporcjach międzyregionalnych wewnątrzkrajowych, gdzie w regionie stołecznym skupia się potencjał badawczy kraju przy jego deficycie $\mathrm{w}$ pozostałych regionach. Wyjątek stanowią tutaj Czechy, gdzie regionem o najwyższej intensywności B $+R$ jest Południowy Wschód - Jyhovychod (CZ06) z aglomeracją Brna jako ośrodkiem akademickim i gospodarczym, a region stołeczny (CZ01) plasuje się tuż za nim. Natomiast trzeci region - Czechy Środkowe - Stredni Czechy (CZ02), korzystając z bezpośredniej bliskości stolicy oraz lokalizacji branży motoryzacyjnej, osiąga 
znaczące w skali kraju nakłady na B+R. Należy zaznaczyć, że cztery z nowych krajów członkowskich (Estonia, Litwa, Łotwa i Malta) stanowią tylko jeden region NUTS 2, co uniemożliwia analizę wewnątrzkrajowych zróżnicowań międzyregionalnych.

Tabela 2. Intensywność nakładów na $\mathrm{B}+\mathrm{R}$ w regionach nowych państw członkowskich UE w 2013 r.

\begin{tabular}{|c|c|c|c|c|c|c|}
\hline Kraj & $\begin{array}{c}\text { GERD } \\
\text { jako \% } \\
\text { PKB } \\
\text { kraju }\end{array}$ & $\begin{array}{l}\text { Dystans } \\
\text { kraju do } \\
\text { średniej } \\
\text { UE-28 }\end{array}$ & $\begin{array}{c}\text { Liczba } \\
\text { NUTS } 2\end{array}$ & $\begin{array}{c}\text { Region } \\
\text { o najwyższej } \\
\text { intensyw- } \\
\text { ności B+R }\end{array}$ & $\begin{array}{l}\text { Region } \\
\text { o najniższej } \\
\text { intensyw- } \\
\text { ności B+R }\end{array}$ & $\begin{array}{l}\text { Liczba regio- } \\
\text { nów poniżej } \\
\text { średniej } \\
\text { dla kraju }\end{array}$ \\
\hline Bułgaria & 0,63 & $-1,39$ & 6 & 1,11 & 0,15 & 5 \\
\hline Chorwacja & 0,81 & $-1,21$ & 2 & 1,00 & 0,42 & 1 \\
\hline Czechy & 1,90 & $-0,12$ & 8 & 2,84 & 0,36 & 5 \\
\hline Estonia & 1,72 & $-0,30$ & 1 & - & - & - \\
\hline Litwa & 0,95 & $-1,07$ & 1 & - & - & - \\
\hline Łotwa & 0,61 & $-1,41$ & 1 & - & - & - \\
\hline Malta & 0,77 & $-1,25$ & 1 & - & - & - \\
\hline Polska & 0,87 & $-1,15$ & 16 & 1,55 & 0,23 & 12 \\
\hline Rumunia & 0,39 & $-1,63$ & 8 & 0,81 & 0,06 & 7 \\
\hline Słowacja & 0,82 & $-1,20$ & 4 & 1,67 & 0,34 & 3 \\
\hline Słowenia & 2,58 & 0,56 & 2 & 3,01 & 2,09 & 1 \\
\hline Węgry & 1,39 & $-0,63$ & 7 & 1,77 & 0,73 & 6 \\
\hline
\end{tabular}

Źródło: Opracowanie własne na podstawie: [Eurostat, 2018].

Słabości nowych państw członkowskich UE w potencjale badawczo-rozwojowym wiązać należy z niższym niż w krajach „starej” Unii poziomem rozwoju gospodarczego. Tym niemniej nie bez znaczenia jest fakt, że w geograficznej przestrzeni Unii Europejskiej kraje te zlokalizowane są na jej obrzeżach, czyli na peryferiach, co nie sprzyja regionalnej specjalizacji w działalności badawczo-rozwojowej. Doskonale sytuację tę obrazuje regionalna mapa intensywności nakładów na $\mathrm{B}+\mathrm{R}$ w $\mathrm{UE}$ (rys. 2).

Intensywność nakładów na B+R w UE-28 kształtowała się w 2013 r. na poziomie 2,02\% , należy jednak stwierdzić występowanie znaczących różnic między regionami $\mathrm{z}$ tendencją do silnej koncentracji geograficznej. Tylko trzydzieści regionów NUTS 2 przekroczyło poziom 3\% PKB przeznaczanego na $\mathrm{B}+\mathrm{R}$, przy czym dziesięć $z$ nich znajduje się w Niemczech, pięć w Wielkiej Brytanii, po cztery w Austrii i Szwecji, trzy w Finlandii, dwa w Belgii oraz po jednym we Francji i Danii. W tych regionach koncentruje się ponad $1 / 3$ całkowitych nakładów Unii Europejskiej na $B+R$. Jak już wcześniej wskazano, geograficzna koncentracja nakładów na $\mathrm{B}+\mathrm{R}$ wynika $\mathrm{z}$ przewagi konkurencyjnej związanej $\mathrm{z}$ występowaniem 
znaczących ośrodków akademickich i badawczych oraz lokalizacją przedsiębiorstw wysokich technologii, a także z korzystnego otoczenia przyciągającego startupy oraz wysoko wykwalifikowany personel [European Union, 2017, s. 151-156]. Wysoka intensywność B + R cechuje w niektórych przypadkach regiony stołeczne lub sąsiadujące $\mathrm{z}$ nimi, jak to ma miejsce $\mathrm{w}$ przypadku regionów szwedzkich, fińskich, austriackich, regionu Berlina, Sztokholmu, Helsinek, Kopenhagi i Wiednia. Jednak część regionów z czołówki nie jest związana z przestrzenną bliskością stolicy, a o ich potencjale $B+R$ decyduje tradycyjnie silnie rozwinięta działalność badawczo-rozwojowa (francuskie Środkowe Pireneje, regiony brytyjskie i belgijskie czy też regiony niemieckie).

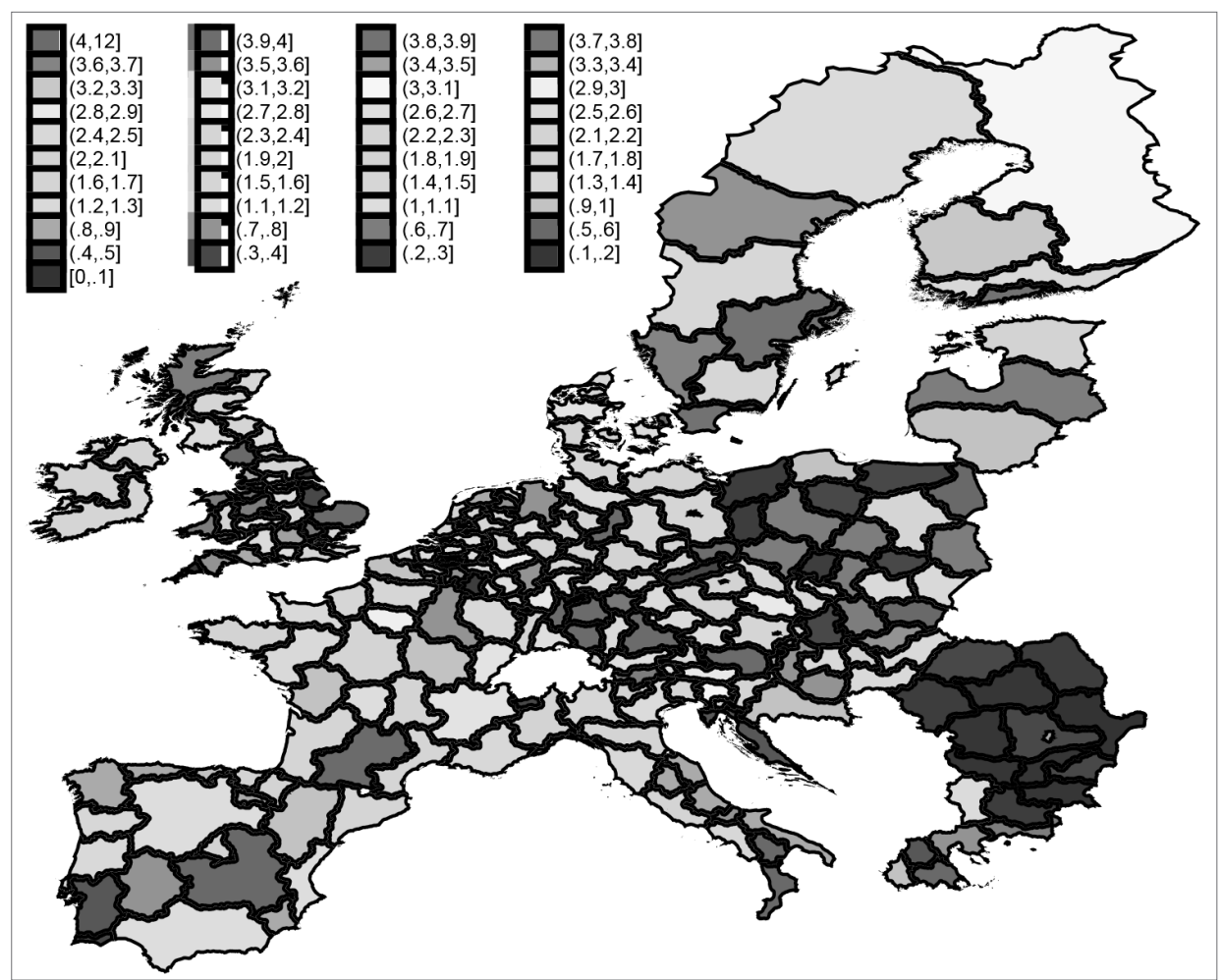

Rysunek 2. Intensywność nakładów na B+R w regionach UE-28 w 2013 r. (w \%) Źródło: Opracowanie własne w programie Stata na podstawie: [Eurostat, 2017].

Poza czołową trzydziestką NUTS 2 trzeba wskazać na względnie skromne wyniki pozostałych zachodnich i północnych regionów UE oraz wyraźnie niską intensywność B $+\mathrm{R}$ w przypadku regionów wschodnich i południowych. Ponadto widoczne są bardzo duże dysproporcje między regionami w poszczególnych krajach, a niejednokrotnie regiony o najwyższej intensywności $B+R$ sąsiadują 
z regionami o bardzo niskiej intensywności $B+R$. Ponadto nietypowa sytuacja występuje w czterech regionach stołecznych (Holandii, Irlandii, Wielkiej Brytanii i Belgii), gdzie intensywność $B+R$ jest niższa niż średnia krajowa.

\section{Opis metody badawczej}

Przestrzenna autokorelacja to statystyczna miara stopnia zależności między obserwacjami w geograficznej przestrzeni (między jednostkami przestrzennymi, dla których zaobserwowano i zmierzono jakieś zjawisko). W celu zmierzenia autokorelacji przestrzennej używa się statystyki Morana $I$, która służy do pomiaru zarówno globalnej, jak i lokalnej autokorelacji przestrzennej. Statystyka Morana I jest miarą globalnej autokorelacji przestrzennej opracowaną przez Morana [1948; 1950]:

$$
I=\frac{N}{\sum_{i} \Sigma_{j} w_{i j}} \cdot \frac{\Sigma_{i} \Sigma_{j} w_{i j}\left(X_{i}-\bar{X}\right)\left(X_{j}-\bar{X}\right)}{\Sigma_{i}\left(X_{i}-\bar{X}\right)^{2}}
$$

gdzie:

$N$ - liczba jednostek przestrzennych oznaczonych indeksami $i$ oraz $j$,

$X$ - interesująca nas zmienna (variable of interest),

$\bar{X}$ - średnia wartość zmiennej $X$,

$w_{i j}$ - element macierzy wag przestrzennych (macierzy sąsiedztwa).

Jeżeli macierz wag przestrzennych jest macierzą standaryzowaną wierszami, to wartości I mieszczą się w przedziale domkniętym od -1 do $+1^{1}$. Wartości ujemne (dodatnie) wskazują na występowanie ujemnej (dodatniej) autokorelacji przestrzennej. Z kolei zerowa wartość $I$ informuje o losowym rozmieszczeniu jednostek przestrzennych pod względem wartości interesującej nas zmiennej. Ponadto wartości I mogą być statystycznie istotne lub statystycznie nieistotne. Oczekiwana wartość I przy założeniu prawdziwości hipotezy zerowej o braku przestrzennej autokorelacji wynosi $\mathrm{E}(I)=-1 /(N-1)$. Dodatnie i statystycznie istotne wartości I oznaczają występowanie klastrów (jednostek przestrzennych o podobnych niskich lub wysokich wartościach intersującej nas zmiennej). Z kolei ujemne i statystycznie istotne wartości I wskazują na obecność tzw. jednostek odstających (outliers), czyli pojedynczych jednostek przestrzennych otoczonych jednostkami o odmiennych wartościach interesującej nas zmiennej [szerzej zob. Cliff, Ord, 1973; Cliff, Ord, 1981; Goodchild, 1986; Kopczewska, 2006]. Dodatkowo, lokalna statystyka Morana $I_{i}$ mierzy, czy jednostka przestrzenna oznaczona indeksem $i$ jest otoczona przez jednostki o zbliżonej czy różnej wartości intere-

1 W przeciwnym przypadku wartości I mogą być wyższe od +1 lub niższe niż -1, choć przeważnie zawierają się $\mathrm{w}$ przedziale domkniętym od -1 do +1 . 
sującej nas zmiennej (w porównaniu z losowym rozmieszczeniem jednostek przestrzennych pod względem wartości interesującej nas zmiennej). Ujemna i statystycznie istotna wartość $I_{i}$ oznacza, że jednostka przestrzenna $i$ jest tzw. jednostką odstającą (outlier). Natomiast dodatnia i statystycznie istotna wartość $I_{i}$ informuje, że jednostka przestrzenna $i$ wchodzi w skład klastru [Kopczewska, 2006].

\section{Wyniki analizy autokorelacji przestrzennej}

W celu zbadania istnienia przestrzennej autokorelacji między regionami NUTS 2 UE-28 w przypadku intensywności nakładów na $B+R$ przyjęto próbę badawczą, która obejmuje 251 regionów NUTS 2 należących do 28 państw członkowskich UE. Próba badawcza uwzględnia wszystkie regiony NUTS 2 z wyłączeniem takich, które nie posiadają lądowego sąsiada w Unii Europejskiej.

W badaniu wykorzystano dane odnośnie do wskaźnika GERD jako procent PKB za ostatni dostępny rok, czyli 2013 r. z bazy danych Eurostatu [2017]. Z uwagi na brak danych dla dwóch regionów niemieckich (DE22 oraz DE23), przyjęto dla nich wartość średnią dla Niemiec $(2,55 \%)$.

Skonstruowano dwie macierze wag przestrzennych, które następnie zostały wystandaryzowane wierszami:

- W1: oparta na koncepcji, że jeżeli dwa regiony posiadają wspólną granicę lądową, traktowane są jako regiony sąsiadujące (wartość $1 \mathrm{w}$ macierzy sąsiedztwa; w przeciwnym przypadku wartość $0 \mathrm{w}$ macierzy sąsiedztwa);

- W2: oparta na koncepcji, że siłę przestrzennych relacji mierzy odwrotność odległości między geometrycznymi środkami regionów.

Tabela 3. Globalna autokorelacja przestrzenna

\begin{tabular}{|c|c|c|}
\hline Zmienna/macierz wag przestrzennych & W1 & W2 \\
\hline Intensywność nakładów na B+R & $I=0,140^{* * *}$ & $I=0,022^{* * *}$ \\
\hline
\end{tabular}

*** Statystyczna istotność na poziomie $1 \%$.

Źródło: Obliczenia własne w programie Stata.

W przypadku macierzy W1 można potwierdzić istnienie bardzo słabej (i statystycznie istotnej na poziomie 1\%) autokorelacji przestrzennej. To oznacza, że regiony sąsiadujące ze sobą cechują się nieznacznie podobnymi wartościami intensywności nakładów na $B+R$. Natomiast w przypadku macierzy W2 należy stwierdzić brak autokorelacji przestrzennej (tab. 3).

Ponadto bardzo słabą autokorelację przestrzenną, a nawet jej brak, potwierdzają wartości lokalnych statystyk Morana. W przypadku macierzy W1 możemy 
wyodrębnić jedynie dwa klastry (istotnie statystyczne dodatnie i wysokie - powyżej 1 lub bliskie 1 - wartości lokalnych statystyk Morana podane w nawiasach): regiony belgijskie BE21 $\left(1,032^{* * *}\right)$, BE24 $\left(2,628^{* * *}\right)$ i BE31 $\left(1,828^{* * *}\right)$ oraz regiony niemieckie DE11 $\left(1,402^{* * *}\right)$, DE12 $\left(1,786^{* * *}\right)$, DE14 $\left(2,775^{* * *}\right)$, DE25 $\left(1,068^{* * *}\right)$ i DE71 $\left(0,791^{* *}\right)$. W przypadku macierzy W2 klastry nie występują w ogóle.

Pierwszy klaster tworzą trzy regiony belgijskie: Antwerpia - Antwerpen (BE21), Brabancja Flamandzka - Vlaams-Brabant (BE24) oraz Brabancja Walońska (BE31). Intensywność nakładów na $\mathrm{B}+\mathrm{R}$ w regionach wynosiła w $2013 \mathrm{r}$. kolejno $2,69 \%, 3,96 \%$ oraz $8,8 \%$. Podkreślić należy, że regiony te znajdują się na czele regionów w Belgii pod względem potencjału $B+R$, a Brabancja Walońska jest liderem w UE, natomiast Brabancja Flamandzka jest $\mathrm{w}$ najlepszej trzydziestce regionów unijnych. $W$ każdym z regionów znajdują się renomowane uniwersytety (Universiteit Antwerpen, Katholieke Universiteit Leuven, Université Catholique de Louvain) oraz instytuty badawcze o profilu technologicznym, w tym także węzły wiedzy i innowacji w ramach Europejskiego Instytutu Technologicznego (w regionie Antwerpii i Brabancji Flamandzkiej). We wszystkich trzech regionach funkcjonują parki naukowe, przyciągające firmy wysokich technologii. Gospodarka Antwerpii bazuje na przemyśle maszynowym, chemicznym, farmaceutycznym (lokalizacja firmy Janssen Pharmaceutica) oraz branży kreatywnej, w Brabancji Flamandzkiej rozwinięte są usługi wiedzointensywne, IT oraz branża medyczna, natomiast gospodarka Brabancji Walońskiej opiera się na branży medycznej (w tym farmaceutycznej z GlaxoSmithKline Biologicals), IT oraz chemicznej. Można zatem wskazać na wspólne dla trzech regionów specjalizacje w branżach wiedzochłonnych, jak branża medyczna/farmaceutyczna, chemiczna i IT. Tak ukierunkowane specjalizacje przedsiębiorst $\mathrm{w} w$ regionach mogą mieć znaczenie dla wykształcenia się różnorodnych powiązań, w tym biznesowych. Wydaje się, że dla powstania tego klastra istotne są także kwestie kulturowo-historyczne, gdyż językiem urzędowym w Antwerpii i Brabancji Flamandzkiej jest język niderlandzki (obie prowincje należą do Flandrii), natomiast Brabancja Flamandzka i Brabancja Walońska do 1995 r. stanowiły jeden region.

Z kolei drugi zidentyfikowany klaster obejmuje pięć regionów niemieckich: Stuttgart (DE11), Karlsruhe (DE12), Tybinga (DE14), Środkowa Frankonia - Mittelfranken (DE25) i Darmstadt (DE71), które cechuje wysoka intensywność B+R (tab. 4). Trzy pierwsze z nich (w Badenii-Wirtembergii) znajdują się w pierwszej dziesiątce regionów UE pod względem intensywności nakładów na $B+R$. Z kolei dwa kolejne, bawarski region Środkowej Frankonii oraz Darmstadt (z Hesji), plasują się w pierwszej trzydziestce regionów UE. We wszystkich pięciu regionach znajdują się duże ośrodki akademickie i instytucje naukowe ( $w$ tym węzeł wiedzy i innowacji Europejskiego Instytutu Technologicznego w regionie Karlsruhe, Europejskie Centrum Operacji Kosmicznych w Darmstadcie, Max Planck Institute w Tybindze). We wszystkich regionach sfera biznesu wykazuje wysoką aktyw- 
ność $\mathrm{w}$ nakładach na $\mathrm{B}+\mathrm{R}$ i realizuje ponad trzy czwarte $\mathrm{B}+\mathrm{R}$ regionu (poza regionem Karlsruhe), a w regionie Stuttgart jest to niemal 92\% (tab. 4).

Tabela 4. Cechy regionów w klastrze niemieckim

\begin{tabular}{|c|c|c|c|c|}
\hline Region & $\begin{array}{l}\text { GERD } \\
\text { jako } \\
\% \text { PKB }\end{array}$ & $\begin{array}{l}\text { BERD } \\
\text { jako } \\
\% \text { GERD }\end{array}$ & Branże dominujące & Firmy \\
\hline DE11 & 5,97 & 91,79 & $\begin{array}{l}\text { motoryzacyjna, ICT, IT, } \\
\text { energetyczna, kreatywna }\end{array}$ & $\begin{array}{l}\text { Daimler, Porsche, Robert Bosch, HP, } \\
\text { IBM, Alcatel-Lucent, Neoplan }\end{array}$ \\
\hline DE12 & 4,26 & 61,97 & $\begin{array}{l}\text { motoryzacyjna, elektro- } \\
\text { techniczna, IT, chemiczna }\end{array}$ & $\begin{array}{l}\text { Michelin, Daimler, Siemens, Robert } \\
\text { Bosch, L'Oreal, Pfizer, ABB, Caterpi- } \\
\text { lar, IBM, Unilever }\end{array}$ \\
\hline DE14 & 4,64 & 79,96 & $\begin{array}{l}\text { IT, chemiczna, medyczna/ } \\
\text { biotechnologiczna }\end{array}$ & CHT/BEZEMA, Zanker, Walker \\
\hline DE25 & 3,75 & 74,40 & $\begin{array}{l}\text { elektrotechniczna, moto- } \\
\text { ryzacyjna, optyczna, } \\
\text { medyczna }\end{array}$ & $\begin{array}{l}\text { Siemens, Robert Bosch, Man, AEG, } \\
\text { Novartis, GFK, Schaeffler, Puma, } \\
\text { Adidas, Nestle, Apollo Optic, Areva }\end{array}$ \\
\hline DE71 & 3,09 & 79,29 & chemiczna, IT, finansowa & $\begin{array}{l}\text { Merck, Wella, Deutsche Bank, ING, } \\
\text { Software AG, Rowenta, Danfoss, } \\
\text { Honda, Hyundai, Hoechst }\end{array}$ \\
\hline
\end{tabular}

Źródło: Opracowanie własne na podstawie: [Eurostat, 2018; European Commission, 2018; oficjalne strony internetowe regionów].

Można wskazać na podobieństwa $\mathrm{w}$ specjalizacji gospodarek $\mathrm{w}$ branżach motoryzacyjnej (w 3 regionach), IT ( $w 4$ regionach), chemicznej ( $w 2$ regionach), elektrotechnicznej ( $w 2$ regionach) i medycznej (w 2 regionach). Co więcej, rodzime korporacje, jak Daimler, Bosch i Siemens, mają swoje jednostki w regionach klastra (tab. 4), co z pewnością sprzyja międzyregionalnym powiązaniom biznesowym. Ponadto swoje centra badawczo-rozwojowe umieściły w Darmstadcie Honda i Hyundai z uwagi na sąsiedztwo z regionem Stuttgartu, w którym zlokalizowani są rodzimi producenci z branży motoryzacyjnej (Daimler, Porsche).

\section{Podsumowanie}

Analiza statystyczna potwierdziła istnienie bardzo słabej autokorelacji przestrzennej globalnej i lokalnej w przypadku sąsiedztwa lądowego regionów NUTS 2, natomiast brak autokorelacji przestrzennej w przypadku sąsiedztwa opartego na odwrotności odległości geograficznej między regionami.

Sąsiedztwo lądowe wydaje się sprzyjać powstawaniu klastrów regionów podobnych pod względem potencjału badawczego, zwłaszcza w regionach, które mają odpowiednią masę krytyczną (wysoką intensywność B+R). Można przy- 
puszczać, że następują wówczas procesy nawiązywania relacji gospodarczych z regionami sąsiednimi. Należy jednak mieć na uwadze, że w wyniku analizy zidentyfikowano tylko dwa klastry, skupione wprawdzie wokół regionów z czołówki UE pod względem intensywności B+R, jednak nie jest to regułą. Prawdopodobnie występowanie klastrów NUTS 2 wiąże się ze złożonymi uwarunkowaniami nie tylko gospodarczymi, ale także społeczno-kulturowymi oraz politycznymi. O tych ostatnich świadczy fakt, że każdy z ujawnionych klastrów znajduje się w obrębie jednego kraju (Belgii i Niemiec).

Można wskazać na pewne prawidłowości w występowaniu klastrów, a mianowicie regiony sąsiadujące ze sobą cechuje podobieństwo regionalnej specjalizacji, które sprzyja nawiązywaniu relacji biznesowych. Firmy zlokalizowane w regionie intensywnie angażują się w realizację nakładów na $B+R$. Ponadto istotną rolę odgrywają silne ośrodki akademickie i badawcze, które mają siłę przyciągania do współpracy firm spoza regionu oraz stanowią zaplecze kapitału ludzkiego.

Należy także wspomnieć o ograniczeniach w niniejszym badaniu. Po pierwsze, statystyki Morana mają liczne wady i są narzędziem dość archaicznym, choć wciąż pozostają podstawową miarą autokorelacji przestrzennej, podobnie jak współczynnik Pearsona w przypadku korelacji liniowej. Po drugie, macierze wag przestrzennych zostały oparte wyłącznie na sąsiedztwie lądowym i odwrotności odległości geograficznych, a być może wskazane byłoby uwzględnienie także kwestii infrastrukturalnych, społecznych czy politycznych.

\section{Źródła finansowania}

Publikacja została dofinansowana ze środków przyznanych Wydziałowi Ekonomii i Stosunków Międzynarodowych Uniwersytetu Ekonomicznego w Krakowie $\mathrm{w}$ ramach dotacji na utrzymanie potencjału badawczego.

Udział Pawła Folfasa w projekcie został sfinansowany ze środków Narodowego Centrum Nauki (numer rejestracyjny projektu: 2015/17/B/HS4/02075).

\section{Bibliografia}

Alexiadis S., Korres G.M., 2010, Adoption of Technology and Regional Convergence in Europe, European Spatial Research And Policy, vol. 17, no. 2.

Archibugi D., Filippetti A., 2011, Is the Economic Crisis Impairing Convergence in Innovation Performance across Europe?, Journal of Common Market Studies, vol. 49, issue 6.

Aristovnik A., 2014, Efficiency of the RED Sector in the EU-27 at the Regional Level. An Application of DEA, MPRA Paper, no. 59081.

Bachtler J., Wren C., 2006, Evaluation of European Union Cohesion policy. Research questions and policy challenges, Regional Studies, no. 40:02.

Barber M.J., Scherngell T., 2013, Is the European RED Network Homogeneous? Distinguishing Relevant Network Communities Using Graph Theoretic and Spatial Interaction Modelling Approaches, Regional Studies, no. 47:8. 
Benos N., Karagiannis S., Karkalakos S., 2015, Proximity and growth spillover in European regions. The role of geographical, economic and technological linkages, Journal of Macroeconomics, vol. 43.

Bilbao-Osorio B., Rodríguez-Pose A., 2004, From RED to innovation and economic growth in the $E U$, Growth and Change, vol. 35, no. 4.

Bottazzi L., Peri G., 2002, Innovation and Spillovers in Regions. Evidence from European Patent Data, IGIER - Universita Bocconi Working Paper, no. 215.

Cliff A.D., Ord J.K., 1973, Spatial Autocorrelation, Pion, London.

Cliff A.D., Ord J.K., 1981, Spatial Process. Models and Applications, Pion, London.

Dominicis L. de, Florax R.J.G.M., Groot H.L.F. de, 2011, Regional Clusters of Innovative Activity in Europe. Are Social Capital and Geographical Proximity the Key Determinants?, Tinbergen Institute Discussion Paper, no. 11-009/3, Tinbergen Institute, Amsterdam Rotterdam.

European Commission, 2009, Europe's regional research systems. Current trends and structures, European Commission, Brussels.

European Commission, 2018, Regional Innovation Monitor Plus, baza danych, https://ec.europa. eu/growth/tools-databases/regional-innovation-monitor/ [dostęp: 30.01.2018].

European Union, 2017, Eurostat regional yearbook. 2017 Edition, European Union, Luxembourg.

Eurostat, 2017, General and regional statistics, baza danych, http://appsso.eurostat.ec.europa. eu/nui/show.do?dataset=rd_e_gerdreg\&lang=en [dostęp: 07.03.2017].

Eurostat, 2018, General and regional statistics, baza danych, http://appsso.eurostat.ec.europa. eu/nui/show.do?dataset=rd_e_gerdreg\&lang=en [dostęp: 10.01.2018].

Frietsch R., Rammer Ch., Schubert T., 2015, Heterogeneity of Innovation Systems in Europe and Horizon 2020, Intereconomics, no. 1.

Furková A., Chocholatá M., 2017, Interregional RED spillovers and regional convergence. A spatial econometric evidence from the EU regions, Equilibrium. Quarterly Journal of Economics and Economic Policy, vol. 12, no. 1.

Goodchild M.F., 1986, Spatial Autocorrelation, Geo Books, London.

Gossling T., Rutten R., 2007, Innovation in Regions, European Planning Studies, vol. 15, no. 2.

Kopczewska K., 2006, Ekonometria i statystyka przestrzenna, CeDeWu, Warszawa.

Maggioni M.A., Uberti T.E., 2007, Inter-regional knowledge flows in Europe. An econometric analysis, [w:] Applied Evolutionary Economics and Economic Geography, ed. K. Frenken, Edward Elgar, Cheltenham - Northamptom.

Martín C., Mulas-Granados C., Sanz I., 2005, Spatial distribution of RED expenditure and patent applications across EU regions and its impact on economic cohesion, Investigaciones Regionales, nr 6.

McCann Ph., Ortega-Argilés R., 2015, Smart Specialization, Regional Growth and Applications to European Union Cohesion Policy, Regional Studies, no. 49:8.

Moran P.A.P., 1948, The Interpretation of Statistical Maps, Journal of the Royal Statistical Society, no. 10 (B).

Moran P.A.P., 1950, Notes on Continuous Stochastic Phenomena, Biometrika, vol. 37, issue. 1.

Narula R., Santangelo G.D., 2009, Location, collocation and R\&D alliances in the European ICT industry, Research Policy, no. 38.

Paas T., Vahi T., 2012, Economic Growth, Convergence and Innovation in the EU Regions, Estonian Discussions on Economic Policy, vol. 20, no. 1.

Peiro-Palomino J., 2016, European regional convergence revisited. The role of the intangible assets, The Annals of Regional Science, vol. 57, issue 1. 
Piras G., Postiglione P., Aroca P., 2012, Specialization, RED and productivity growth. Evidence from EU regions, The Annals of Regional Science, no. 49.

Polasek W., Sellner R., 2013, Does Globalization Affect Regional Growth? Evidence For Nuts-2 Regions In Eu-27, Law and Economics Review, vol. 4, no. 1.

Rodríguez-Pose A., 2015, Leveraging research, science and innovation to strengthen social and regional cohesion, European Union, Luxembourg.

Stephan A., Happich M., Geppert K., 2005, Regional Disparities in the European Union. Convergence and Agglomeration, Working paper series, Europa-Universität Viadrina Frankfurt, no. 4 .

Sterlacchini A., 2008, R\&D, higher education and regional growth. Uneven linkages among European regions, Research Policy, no. 37.

Veugelers R., Cincera M., 2015, How to Turn on the Innovation Growth Machine in Europe, Intereconomics, no. 1.

Oficjalne strony internetowe regionów:

Antwerpia, https://www.provincieantwerpen.be/provinciebestuur.html [dostęp: 26.01.2018].

Badenia-Wirtembergia, https://rp.baden-wuerttemberg.de/rpk/Seiten/default.aspx [dostęp: 27.01.2018], https://www.wolfsburg.de/ [dostęp: 28.01.2018].

Brabancja Flamandzka, https://www.vlaamsbrabant.be/ [dostęp: 26.01.2018].

Brabancja Walońska, http://www.brabantwallon.be/bw/ [dostęp: 26.01.2018].

Brunszwik, https://www.hannover.de/en [dostęp: 28.01.2018].

Darmstadt, https://rp-darmstadt.hessen.de// [dostęp: 25.01.2018].

Górna Bawaria, https://www.welcomedahoam.com/en/future/ [dostęp: 26.01.2018].

Region Stołeczny, https://www.regionh.dk/english/Pages/default.aspx [dostęp: 28.01.2018]. Stuttgart, https://www.region-stuttgart.org/andere-laender/english/ [dostęp: 27.01.2018].

Styria, http://www.verwaltung.steiermark.at/ [dostęp: 28.01.2018].

Środkowa Frankonia, http://www.bezirk-mittelfranken.de/index.php?id=609 [dostęp:

25.01.2018], http://www.regierung.mittelfranken.bayern.de/ [dostęp: 25.01.2018].

Środkowe Pireneje, http://www.midipyrenees.fr/ [dostęp: 28.01.2018].

Tybinga, http://www.tuebingen.de/en/ [dostęp: 27.01.2018].

A. Odrobina (®) odrobina@uek.krakow.pl

Katedra Międzynarodowych Stosunków Gospodarczych, Uniwersytet Ekonomiczny w Krakowie, ul. Rakowicka 27, 31-510 Kraków, Polska

P. Folfas (『) pfolfa@sgh.waw.pl

Instytut Ekonomii Międzynarodowej, Kolegium Gospodarki Światowej,

Szkoła Główna Handlowa w Warszawie, ul. Madalińskiego 6/8, 02-513 Warszawa, Polska 